\title{
Empirical Investigation of Symmetric and Asymmetric Target Adjustment Models: Capital Structure of Non-Financial Firms in Jordan
}

\author{
Bashar K. Abu Khalaf ${ }^{1}$ \\ ${ }^{1}$ Assistant Professor, School of Business, The University of Jordan, Jordan \\ Correspondence: Bashar Abu Khalaf, School of Business, The University of Jordan, Amman, 11942, Jordan. Tel. \\ 962-775-558-777. E-mail: B.abukhalaf@ju.edu.jo
}

Received: January 17, 2017

Accepted: February 9, $2017 \quad$ Online Published: February 15, 2017

doi:10.5539/ijef.v9n3p133

URL: https://doi.org/10.5539/ijef.v9n3p133

\begin{abstract}
The different capital structure theories propose the possible asymmetric behavior of capital structure. Thus, this paper empirically investigates whether non-financial Jordanian firms follow symmetrical or asymmetrical adjustment model. Then, an interaction model with the size and profitability (firm characteristics) investigated the impact of low/high profit and small/large size on the adjustment of leverage towards the target leverage ratio. This paper covered the period of 14 years (2002-2015) for a total of 110 companies listed on Amman Stock Exchange (75 industrial and 35 services). Results indicate that although Jordanian firms seek a target leverage ratio, their adjustment towards that target is Asymmetrical and high profitable and large companies tend to adjust faster than low profitable and small size companies.
\end{abstract}

Keywords: target capital structure, symmetric/asymmetric adjustment, size, profitability, ASE

\section{Introduction}

Corporate finance is the economic topic mainly concerned with business funding, decision making as well as mergers and acquisitions. The more important decisions that a firm must take include: investment; Dividend allocation policy and one of the more debated topics of firm decisions is capital structure; which will be the topic investigated in this paper, and can be simply defined as the combination of differently rated classes of debt in a structured financial institution. All the mentioned decisions are taken with long term implications in mind and with the main aim of increasing a companies' shareholder's wealth.

The problematic and debated issue of capital structure has attracted the attention of many researchers from all corners of the business world. Numerous attempts have been made to tackle this issue as a number of researchers have discussed this issue and fashioned theories and approaches. Notable researchers include Modigliani and Miller (1958), Fama and French (2004), Ross et al. (1993), Jensen and Meckling (1976) as well as Myers (2001). The following theories will review the main views regarding capital structure theories from the traditional views as well as the more modern ones.

Modigliani and Miller (1958) can be attributed as the originators of capital structure discussion and theories. Their theory, referred to as the "Traditional Theory", is based on two propositions. The first is that capital structure is irrelevant to a firm's performance, the second states that the cost of equity influences a company's capital structure. They argued that in an ideal market with no tax or bankruptcy costs, a firm's value is not affected by its methods of financing (capital structure). This theory can be attributed as the starting point of capital structure theories. However, the irrelevancy theory was later found to be a purely theoretical model with no empirical foundations by later researchers such as: Ross et al. (1993) and others. Modigliani \& Millers second proposition found that there is no impact of capital structure on the firms' value simply because the different mix of debt and equity has no impact on the Weighted Average Cost of Capital (WACC) of the firm.

A number of researchers also developed theories involving capital structure which will be investigated later on, such as: the two main modern theories, Trade-off theory (Kraus \& Litzenberger, 1973) and the pecking order theory (Myers, 1984). The trade-off theory states that a firm will borrow until the point where the marginal value of the tax shield on additional debt is balanced by increasing the present value of bankruptcy cost (Ross et al., 1993). In addition, the pecking order theory which in brief states that the cost of raising capital increases with 
asymmetric information; firms prefer financing through internal funding using retained earnings followed by debt.

In recent history the continuous theoretical developments in the financial topics have made capital structure one of the most significant topics of discussion today. Most papers discussing this topic have been carried out in developed countries and economies. This paper investigates the partial adjustment models of capital structure for one of the developing countries (Jordan) and most importantly concentrating on the influence of Profitability and Size on the adjustment towards the target leverage ratio.

\section{Theoretical Background}

The base of capital structure empirical discussion can be traced back to Modigliani \& Millers' initial research regarding the irrelevancy theory (1958). This theory can be taken as the cornerstone of this topic. The main concern of this theory is that it provides assumptions of a perfect market exists with no transaction costs, taxes or bankruptcy thus affecting the value of a company is irrelevant of the management's decisions on how to finance their capital. It is documented in different empirical papers that a capital market is far from perfect (Myers \& Majluf, 1984). These imperfections can be seen to put an increasing importance on capital structure; and with the Jordanian market being a developing one these imperfections tend to be greater. Because Modigliani and Miller's study was invalidated; a great number of theories regarding capital structure were developed over the years as a direct result of the criticism of the irrelevancy theory.

Following the irrelevancy theory (1958) of were developments made in capital structure theories derived from that basis such as the previously mentioned tradeoff theory which classically infers that optimal leverage reflects a tradeoff between tax benefits of debt and bankruptcy costs (Kraus \& Litzenberger, 1973). Later, Myers (1984) added that a firm sets an optimal debt ratio and moves towards this target. This theory was later perceived to include two phases, the first being referred to as the static tradeoff theory which states that firms have an optimal capital structure which is determined by trading off the benefits against the cost of debt. The static model does not capture the dynamic adjustment in leverage ratio; the dynamic tradeoff theory takes into account additional factors and states that a firm will adjust to reach its optimal target structure with different speeds. The adjustment by changing debt increases the risk of bankruptcy; moreover, it has been found that it is inherently very difficult to determine a target capital structure.

The second capital structure theory is the pecking order theory, this theory is based on the assumptions that firms prefer financing internally rather than externally and this is reflected in their dividend policy (past investments match expected future ones). The theory derives its name from the manner firms' finance their investments: starting with the least demanding retained earnings and moving on to safe and risky debts while finally reaching equity; in other words they go down the "pecking" order. This theory argues that more profitable firms borrow less as they have more access to internal financing and smaller firms borrow and consequently accumulate debt, altering their capital structure.

The two aforementioned theories rely on the assumption that managers will act with the firm's shareholder's best interests in mind, while this is an ideal scenario. Jensen and Meckling (1976) argued that the agency problem happens when the manager takes the different financial decisions for his or her own benefit and not considering the main aim of the company (Maximizing shareholders wealth). They claimed that the agency problem occurs when managers and shareholders do not always have their interests aligned. This leads to managers wasting free cash flow on bad investments and thus incurring the financial aspect of the agency problem. In order for the shareholders (the principals) to ensure that the agents will make optimal decisions on their behalf, costs must be incurred. These monitoring costs and the resulting residual loss are defined as agency costs. Companies will look to internal financing to incur these costs and as such it can be concluded that in firms where this problem presides; more investments lead to less leverage as they will use a large fraction of their earnings to cover the agency costs.

Table 1. The proposed impact of the two main capital structure theories on the target leverage ratio

\begin{tabular}{lcc}
\hline Theories & Firm Characteristics & Impact \\
\hline Pecking order theory & Profitability & Negative \\
& Size & Positive/Negative \\
Trade-off theory & Profitability & Positive \\
& Size & Positive \\
\hline
\end{tabular}

\section{Methodology}

This paper tries to empirically investigate if the movement towards the target leverage ratio is symmetrical or 
asymmetrical for 110 companies (75 industrial and 35 services) listed on ASE. In order to investigate the impact of the different firm characteristics on the target leverage ratio; pooled and panel analysis (fixed and random effect techniques) were used. The data needed were collected from the annual reports of the different firms and the ASE's website.

\subsection{Literature Review and Models Development}

According to the trade-off theory, firms can optimize their own capital structure because they encounter a trade-off between the advantages and disadvantages of debt on firm's market value; rising leverage by increasing debt means that the firm can benefit from debt tax shields, which will increase its value (Modigliani \& Miller's, 1963). However, high leverage leads to higher expected direct (such as costs of liquidation, administrative and legal costs) and indirect costs (such as agency costs of debt) of financial distress, thus, decreasing the firm's market value. (Ross et al., 2002; Oztekin \& Flannery, 2012).

In order to examine the symmetric adjustment model, we need to construct the target leverage ratio deviation variable $l d e v_{i, t}$ to determine if the actual lagged leverage deviates from the target leverage ratio. the $l d e v_{i, t}$ can be calculated by subtracting the lagged actual leverage ratio from the target leverage ratio of the current year (Tar Levi,t - Act Lev $_{i, t}-1$ ). (Hovakimian \& Li, 2011).

In an ideal optimal world, the target capital structure would be the current capital structure of a firm. However, in practice, a firm may choose not to adjust its capital structure immediately to the target (Flannery \& Hankins, 2013). This will be the case, when the firm faces high adjustment costs or the financial system is not able to provide the financial needs. Based on the above, the following symmetric adjustment model can be presented as:

$$
\Delta \operatorname{Lev}_{i, t}=\beta_{0}+\beta_{1} \text { LLev }_{i, t}+\varepsilon_{i, t}
$$

Where, $\Delta$ Levi, $\mathrm{t}=\left(\right.$ Act Lev $_{i, t}-$ Act Lev $\left._{i, t-1}\right)$ is the net change in leverage, DLevi,t $=\left(\right.$ Tar Lev $_{i, t}-$ Act Lev $\left._{i, t-1}\right)$ measure how far the actual leverage ratio deviates from the target leverage. $\beta 1$ Is the adjustment coefficient that measures the speed of target adjustment. In order for partial adjustment to exist, $\beta$ should be between zero and one $(0<\beta<1)$, not zero or one. At $\beta=1$ a complete adjustment toward the target occurs, implying that (Tar Lev $v_{i, t}=$ Act Lev $_{i, t-1}$ ), while $\beta=0$, no adjustment toward the target take place because the adjustment costs are high enough to eliminate the benefit of moving toward the target (Huang \& Ritter, 2009). $\beta>1$ implies an adjustment more than necessary. To investigate whether they have different adjustment rates, we first study the optimal capital structure ( $\operatorname{Tar} L e v_{i, t}$ ), which is equal to:

$$
\text { Tar } \operatorname{Lev}_{i, t}=\text { Act Lev } \text { L }_{i, t}-\text { Act Lev }_{i, t-1}
$$

Where, Tar Lev $v_{i, t}$ is the targeted leverage ratio, Act Levi, $\mathrm{t}$ is the leverage ratio for firm (i) at time (t). Act $\operatorname{Lev}_{i, t-1}$ is the leverage ratio for firm (i) at time (t-1). Then, we develop the following adjustment models by splitting the values of $\operatorname{Tar}^{L e v} v_{i, t}$ variables.

The two new variables are constructed as follows:

$$
\begin{aligned}
& D L e v_{i, t}^{\text {below }}=\operatorname{Tar}_{\operatorname{Lev}} v_{i, t} \text { if } A c t \operatorname{Lev}_{i, t}-\operatorname{Act}_{L} \operatorname{Lev}_{i, t}-1>0 \text { and zero otherwise } \\
& D L e v_{i, t}{ }^{\text {above }}=\operatorname{Tar} \operatorname{Lev}_{i, t} \text { if Act Levi, } \mathrm{t}-\operatorname{Act} \operatorname{Lev}_{i, t}-1<0 \text { and zero otherwise }
\end{aligned}
$$

By subtracting DLevi, $\mathrm{t}^{\text {below }}$ and $D L e v_{i, t}{ }^{\text {above }}$ from $\operatorname{Tar} \operatorname{Lev}_{i, t}$ we can rewrite the model as follows:

$$
\Delta \operatorname{Lev}_{i, t}=\alpha_{0}+\alpha_{1} \text { DLev }_{i, t}{ }^{\text {above }}+\alpha_{2} \text { LLev }_{i, t}^{\text {below }}+\varepsilon_{\mathrm{i}, \mathrm{t}}
$$

This model provides asymmetric adjustment model specification, where $D$ Lev $v_{i, t}$ below and $D$ Lev $v_{i, t}$ above indicate that the firm's leverage above and below the target capital structure ratio respectively. $\alpha_{1}$ and $\alpha_{2}$ are the adjustment coefficients to be estimated. In addition, the asymmetric adjustment model behavior of $\alpha_{1}$ and $\alpha_{2}$ needs to be statistically significant (greater than and not equal to zero $\alpha_{1} \neq \alpha_{2}$ ). Therefore, the adjustment coefficients mentioned above $\left(\alpha_{1}, \alpha_{2}\right)$ capture the magnitude of response of capital structure ratio when its above and below the target respectively (Hussain et al., 2015). Accordingly, we can argue that if the adjustment costs of increasing leverage are lower than decreasing debt, (then $\alpha_{1}>\alpha_{2}$ ), then the speed of adjustment for Leverage above the target would be slower than for leverage below the target.

The pecking order theory argues that due to asymmetric information between managers and investors, firms that need additional financing prefer internal financing to debt financing and debt financing to issuing shares (Myers, 1984). Therefore, more profitable firms tend to have higher retained earnings and less need for increasing leverage. (Hovakimian et al., 2001; Remolona, 1990; Hovakimian \& Li, 2012). Below we examine a broad set of variables for which one or both theories suggest that they should be included in our analysis. We briefly describe the relationship that we expect with firms' target capital structure and whether this relationship is based on trade-off or pecking order considerations. The previous Table 1 provides a summary of the impact of different 
corporate theories on the optimal capital structure debt ratio.

\subsubsection{Size}

Large firms tend to be more diversified, hence, having a lower risk of bankruptcy costs. Furthermore, for large firms, fixed direct bankruptcy costs cover a smaller portion of firm value, leading to relatively lower costs of leverage (Titman \& Wessels, 1988; Chang \& Dasgupta, 2009). Based on the Pecking order larger firms disclose more information which helps the company to be more transparent to the different market participants and this in turn decreases the information asymmetry. Consequently, this study expects smaller companies to move towards the target leverage ratio faster than larger ones. The proxy used for size is the natural logarithm of total assets. Accordingly, two variables (Ssize for small size and Lsize for large size) have been constructed in order to investigate if the adjustment below or above the target leverage ratio varies for small/large companies:

- $\quad$ Lsize = large size companies (interaction between the natural logarithm of total assets variable multiplied by a dummy variable that equals one for the firms that have a natural logarithm of total assets greater than the median, and equals zero otherwise).

- $\quad$ Ssize = small size companies (interaction between the natural logarithm of total assets variable multiplied by a dummy variable that equals one for the firms that have a natural logarithm of total assets lower than the median, and equals zero otherwise).

\subsubsection{Profitability}

Based on the trade-off theory, highly profitable firms increase their debt in order to take better advantage of the tax shield. In addition, Jensen (1986) argued that usually shareholders try to monitor the performance of managers and they keep asking them to increase the company's' leverage in order to reduce the free cash flow available to managers which in turn reduces the agency costs (Byoun, 2008). So, this study expects highly profitable companies to adjust their leverage faster than low profitable ones. The proxy used for the profitability is the return on assets. Then, two variables have been constructed (Lprof for low profitability and Hprof for high profitability) in order to investigate if the adjustment below or above the target leverage ratio varies when companies experience low/high profits:

- Hprof = companies with high profitability (interaction between the return on assets multiplied by a dummy variable which equals one for the firms that have a return on assets greater than the median, and equals zero otherwise).

- Lprof = companies with low profitability (interaction between the return on assets multiplied by a dummy variable that equals one for the firms that have a return on assets lower than the median, and equals zero otherwise).

Interacting the new variables mentioned above in an interaction dummy form with model 2 , model 3 would be as follows:

$$
\begin{aligned}
& \Delta \text { Lev v }_{i, t}=\beta_{0}+\beta_{1} \text { Lprof }_{i, t}+\beta_{2} \text { Hprof }_{i, t}+\beta_{3} \text { Lsize }_{i, t}+\beta_{4} \text { Ssize }_{i, t}+\beta_{5} \text { Dlev below }_{i, t}^{\text {bet }}+\beta_{6} \text { Dlev }_{i, t}^{\text {above }}+\beta_{7} \text { Lprof }_{i, t} * \text { Dlev below }_{i, t}^{\text {bel }} \\
& +\beta_{8} \text { Hprof }_{i, t} * \text { Dlev below }_{i, t}+\beta_{9} \text { Lprof }_{i, t} * \text { Dlev }_{i, t}^{\text {above }}+\beta_{10} \text { Hprof }_{i, t} * \text { Dlev }_{i, t}^{\text {above }}+\beta_{11} \text { Lsize }_{i, t} * \text { Dlev }_{i, t}^{\text {below }} \\
& +\beta_{12} \text { Ssize }_{i, t} * \text { Dlev below }_{i, t}^{\text {belo }}+\beta_{13} \text { Lsize }_{i, t} * \text { Dlev }_{i, t}^{\text {above }}+\beta_{14} \text { Ssize }_{i, t} * \text { Dlev }_{i, t}^{\text {above }}+\varepsilon_{i, t}
\end{aligned}
$$

Where Lprof $_{i, t}$ Hprof $_{i, t}$ Lsize $_{i, t}$, and Ssize $e_{i, t}$ are low profitability, high profitability, large size and small size respectively as explained before. $D L \operatorname{Lev}_{i, t}{ }^{\text {below }}$ and $D \operatorname{Lev}_{i, t}{ }^{\text {above }}$ as explained above. $\operatorname{Lev}_{i, t}{ }^{\text {above }}\left(\operatorname{Lprof}_{i, t}+\operatorname{Hprof}_{i, t}+\right.$ Lsize $_{i, t}+$ Ssize $\left._{i, t}\right)$ is the interaction between the leverage deviation above the target with the different firm characteristics. Lev $_{i, t}{ }^{\text {below }}\left(\operatorname{Lprof}_{i, t}+\operatorname{Hprof}_{i, t}+\operatorname{Lsize}_{i, t}+\right.$ Ssize $\left._{i, t}\right)$ is the interaction between the leverage deviation below the target with the different firm characteristics. In this model the coefficients $\left(\beta_{7}, \beta_{8}, \beta_{9}, \beta_{10}, \beta_{11}, \beta_{12}, \beta_{13}\right.$, and $\beta_{14}$ ) are significant and positive then leverage smoothing exists and these coefficients should not be equal for an asymmetric adjustment to exist. For example, if the coefficient $\left(\beta_{7}\right)$ is significant and positive then low profitable companies smooth their leverage when the leverage is below the target leverage ratio.

\section{Results}

The sample used in this paper has excluded any company that got listed on ASE after 2002, any company that got merged during the period of the study. This paper used Hausman test in order to check the best estimation method (Fixed effect or Random) then the best estimation method was presented. Table 2 shows the descriptive statistics of the constructed variables included in the previous model. Evidently, the Large/Small size variable has the highest standard deviation; this highpoint that there is a variation in the companies size which might affect the capital structure to be different. Moreover, high profitable firms tend to have on average $12.5 \%$ compared to low profitable firms with $-1.5 \%$ and this specify that there is possibly different behaviour towards 
which source of fund to pick first (The pecking order theory).

Table 2. Descriptive statistics

\begin{tabular}{lllll}
\hline & Hprof & Lprof & Lsize & Ssize \\
\hline Mean & 0.125 & -0.015 & 18.250 & 14.980 \\
Std. Dev & 0.107 & 0.054 & 1.150 & 0.486 \\
Min. & 0.041 & -0.859 & 16.450 & 12.492 \\
Max. & 1.468 & 0.040 & 20.643 & 16.449 \\
\hline
\end{tabular}

Note. Hprof is the high profitability. Lprof is the Low profitability. LSize is the large size of the firms. SSize is the small size of the firms.

\subsection{Results of the Symmetric Adjustment Model (Model 1)}

The fixed effect model was found as the best model since the Lagrange Multiplier (LM) and Huasman tests are significant. In addition, the model is significant for the 110 Jordanian companies listed on ASE and the symmetric adjustment model estimation results are presented in Table 3. Table 3 presents a positive significant constant (0.028) and this indicates that Jordanian firms tend not to reduce their Leverage. And most importantly the positive significant coefficient of the deviation of leverage indicates that Jordanian companies tend to smooth their leverage towards the target leverage ratio.

Table 3. Estimation results of the symmetric adjustment model

\begin{tabular}{ll}
\hline Dependent variable $\Delta$ Lev $_{i, t}$ & \\
\hline Intercept & $0.028^{*}$ \\
& $(0.067)$ \\
Lev $_{i, t}$ & $0.514^{*}$ \\
& $(0.000)$ \\
$\mathrm{R}^{2}$ & 0.14 \\
$\mathrm{p}$-value (F-stat) & $(0.000)$ \\
LM Test & 61.49 \\
& $(0.000)$ \\
Hausman Test & 2.25 \\
& $(0.005)$ \\
\hline
\end{tabular}

Note. $\Delta \operatorname{lev}_{\mathrm{i}, \mathrm{t}}$ is the change in leverage and $\operatorname{Dlev}_{\mathrm{i}, \mathrm{t}}$ is the leverage deviation from the target leverage ratio. The symbols $* * * * *$ and $*$ denote statistical significance at $10 \%, 5 \%$ and $1 \%$ levels respectively.

\subsection{Results of the Asymmetric Adjustment Model (Model 2)}

Table 4 provides the results of fixed effect model since the results of the LM and Hausman tests are significant. The results approve that the movement towards the target leverage ratio is asymmetrical simply because the adjustment rates when below or above the target leverage ratio differs; the coefficient of the deviation of leverage for above (0.295) and below (0.575) the target leverage ratio are significant. In other words, the higher adjustment rate for the below the target leverage ratio than above deviation suggests that the non-financial Jordanian companies tend to increase their leverage in order to have more cash flow and this helps in investing in positive net present value projects.

Table 4. Estimation results of the asymmetric adjustment model

\begin{tabular}{ll}
\hline Dependent variable $\Delta L e v_{i, t}$ & \\
\hline Intercept & $0.034^{*}$ \\
& $(0.068)$ \\
Dlev $_{i, t}{ }^{\text {below }}$ & $0.575^{*}$ \\
& $(0.000)$ \\
Dlev $_{i, t}{ }^{\text {above }}$ & $0.295^{*}$ \\
$\mathrm{R}^{2}$ & $(0.000)$ \\
$\mathrm{p}$-value (F-stat) & 0.17 \\
LM Test & $(0.000)$ \\
& 5.57 \\
Hausman Test & $(0.000)$ \\
& 3.15 \\
\end{tabular}

Note. $\Delta \operatorname{lev}_{\mathrm{i}, \mathrm{t}}$ is the change in leverage. $\operatorname{Ddev}_{\mathrm{i}, \mathrm{t}}^{\text {below }}$ is the leverage ratio below the target leverage ratio. ${ }_{\text {Dlev }}$ above is the leverage above the target leverage ratio. The symbols $* * *, * *$ and $*$ denote statistical significance at $10 \%, 5 \%$ and $1 \%$ levels respectively. 


\subsection{Results of the Asymmetric Adjustment Model - Including the Interaction Terms (Model 3)}

Table 5 shows that non-financial Jordanian firms adjust to their target leverage ratio not only asymmetrically for above and below the target capital structure but also asymmetrically for downward and upward leverage adjustments for small/large size companies and when they face low/high profits. The unequal significant positive coefficients $\left(\beta_{7}, \beta_{8}, \beta_{9}, \beta_{10}, \beta_{11}, \beta_{12}, \beta_{13}\right.$ and $\left.\beta_{14}\right)$ suggest the presence of asymmetrical adjustments. In addition, the coefficients $\left(\beta_{1}, \beta_{2}, \beta_{3} \beta_{4}, \beta_{5}\right.$ and $\left.\beta_{6}\right)$ are significant which suggests that the small/large size and low/high profitable Jordanian companies are unwilling to reduce their leverage.

Table 5. Estimation results of the asymmetric adjustment model with firm characteristics interaction (profitability, leverage and size)

\begin{tabular}{|c|c|c|c|}
\hline \multicolumn{4}{|c|}{ Dependent variable $\Delta L e v_{i, t}$} \\
\hline Independent Variables & Beta & Coefficient & probability \\
\hline Intercept & $\beta_{0}$ & $0.051^{* * *}$ & $(0.065)$ \\
\hline $\operatorname{Lprof}_{i, t}$ & $\beta_{1}$ & $0.698^{* *}$ & $(0.029)$ \\
\hline Hprof $_{i, t}$ & $\beta_{2}$ & $0.540^{*}$ & $(0.030)$ \\
\hline$L s i z e_{i, t}$ & $\beta_{3}$ & $0.195^{* *}$ & $(0.055)$ \\
\hline Ssize $_{i, t}$ & $\beta_{4}$ & $0.254^{*}$ & $(0.000)$ \\
\hline $\operatorname{Ldev}_{i, t}$ below & $\beta_{5}$ & $0.650^{*}$ & $(0.000)$ \\
\hline Ldeviti ${ }_{i b o v e}$ & $\beta_{6}$ & $0.540^{*}$ & $(0.000)$ \\
\hline $\operatorname{Lprof}_{i, t} * \operatorname{Ldev}_{i, t}{ }^{\text {below }}$ & $\beta_{7}$ & $0.759^{*}$ & $(0.000)$ \\
\hline $\operatorname{Hprof}_{i, t} * \operatorname{Ldev}_{i, t}{ }^{\text {below }}$ & $\beta_{8}$ & $0.258^{*}$ & $(0.000)$ \\
\hline $\operatorname{Lprof}_{i, t} * \operatorname{Ldev}_{i, t}{ }^{\text {above }}$ & $\beta_{9}$ & $0.348^{*}$ & $(0.000)$ \\
\hline Hprof $_{i, t}{ }^{*}$ Ldev $_{i, t}{ }^{\text {above }}$ & $\beta_{10}$ & $0.579^{*}$ & $(0.001)$ \\
\hline Lsize $_{i, t} *$ Ldev $_{i, t}^{\text {below }}$ & $\beta_{11}$ & $0.185^{*}$ & $(0.000)$ \\
\hline Ssize $_{i, t}{ }^{*}$ dev $_{i, t}$ below & $\beta_{12}$ & $0.390^{* *}$ & $(0.055)$ \\
\hline $\operatorname{Lsize}_{i, t}{ }^{*} \operatorname{Ldev}_{i, t}{ }^{\text {above }}$ & $\beta_{13}$ & $0.385^{* *}$ & $(0.030)$ \\
\hline Ssize $_{i, t} * \operatorname{Ldev}_{i, t}{ }^{\text {above }}$ & $\beta_{14}$ & $0.853^{*}$ & $(0.000)$ \\
\hline $\mathrm{R}^{2}$ & & 0.29 & \\
\hline p-value (F-stat) & & $(0.000)$ & $(0.001)$ \\
\hline LM Test & & 10.37 & \\
\hline Hausman Test & & 12.64 & $(0.449)$ \\
\hline
\end{tabular}

Note. All variables as explained above in the different models. The symbols $* * *, * *$ and $*$ denote statistical significance at $10 \%, 5 \%$ and $1 \%$ levels respectively.

Furthermore, the significant positive estimated coefficients $\left(\beta_{11}+\beta_{12}, \beta_{13}\right.$ and $\left.\beta_{14}\right)$ suggest that small non-financial Jordanian companies smooth their leverage and adjust to their target capital structure slower than larger firms. This result is in line with Al-Najjar \& Hussainey (2009) argument that large companies in Jordan experience low transaction costs and the bankruptcy cost is low. Consequently, large non-financial companies adjust their leverage faster than smaller ones because they do have easy access to the market and can increase their funds easier - the regulators in ASE concentrate and focus more on large companies since they disclose more information and they follow the rules of transparency better than smaller ones (Al-Najjar \& Hussainey, 2009). This result confirms the predictions of the model suggested by Redding (1997) that the likelihood of large and liquid companies to increase their leverage is higher than smaller ones as increasing leverage would decrease the free cash flow available to managers and this in turn reduces the agency problem.

Also, the significant positive coefficients $\left(\beta_{7}+\beta_{8}, \beta_{9}\right.$ and $\left.\beta_{10}\right)$ suggest that because of the low transaction costs faced by the highly profitable companies; they adjust their leverage towards their target leverage ratio faster than lower ones. This result confirms the predictions of the signalling theory which proposes that the managers of highly profitable firms tend to signal their greater confidence in the future cash flows and to assure the shareholders that the company will keep smoothing leverage toward the target leverage ratio. This result also agrees with the findings of Al-Malkawi (2007) where he concluded that highly profitable Jordanian companies increase their leverage than less profitable firms. Accordingly, highly profitable non-financial Jordanian companies experience better cash flows and this allows them to move to the target leverage ratio more quickly.

\section{Conclusion}

This empirical paper used panel data in order to investigate 110 listed firms on ASE (75 industrial and 35 
services) during the period 2002-2015. This paper investigated the smoothness of target capital structure using symmetric and asymmetric partial adjustment models and the impact of firm characteristics (large/small size and high/low profit) on the asymmetric adjustment model. This paper found that non-financial firms move toward their target capital structure asymmetrically at a moderate adjustment rate. And according to agency cost theory large companies smooth their leverage faster towards the target leverage ratio; which indicates that companies in Jordan use leverage to decrease the free cash flow available to managers so they cannot invest in unprofitable projects in order to reduce agency cost. Moreover, the higher the company's profit the better is the financial position of the firm; so it can increase its leverage and signal good healthy confident future of cash flow to service its debt. Consequently, the partial adjustment model for the non-financial Jordanian firms is asymmetric and influenced by the size and profitability.

\section{Acknowledgments}

I would like to acknowledge the financial support received from the Deanship of Scientific Research, The University of Jordan. In addition, I would like to thank Mr. Mohamed Alnasr for being a research assistant throughout this empirical paper.

\section{References}

Booth, L., Aivazian, V., Demirgüç-Kunt, A., \& Maksimovic, V. (2001). Capital structures in developing countries. Journal of Finance, 56, 87-130. https://doi.org/10.1111/0022-1082.00320

Byoun, S. (2008). How and when do firms adjust their capital structure toward targets? Journal of Finance, 63, 3069-3096. https://doi.org/10.1111/j.1540-6261.2008.01421.x

Chang, X., \& Dasgupta, S. (2009). Target behavior and financing: How conclusive is the evidence? Journal of Finance, 64, 1767-1796. https://doi.org/10.1111/j.1540-6261.2009.01479.x

DeAngelo, H., \& Masulis, R. W. (1980). Optimal capital structure under corporate and personal taxation. Journal of Financial Economics, 8, 3-29. https://doi.org/10.1016/0304-405X(80)90019-7

Fama, E., \& French, K. (2002). Testing Trade-Off and Pecking Order Predictions About Dividends and Debt. The Review of Financial Studies, 15, 1-33. https://doi.org/10.1093/rfs/15.1.1

Flannery, M., \& Hankins, K. W. (2013). Estimating dynamic panels in corporate finance. Journal of Corporate Finance, 19, 1-19. https://doi.org/10.1016/j.jcorpfin.2012.09.004

Gujarati, D. N. (2003). Basic Econometrics (4th ed.). Irwin/McGraw-Hill, USA.

Harris, M., \& Raviv, A. (1991). The theory of capital structure. Journal of Finance, 46, 297-355. https://doi.org/10.1111/j.1540-6261.1991.tb03753.x

Heshmati, A. (2002). The dynamics of capital structure: Evidence from Swedish micro and small firms. Research in Banking and Finance, 2, 199-241.

Hovakimian, A., \& Li, G. (2011). In search of conclusive evidence: How to test for adjustment to target capital structure. Journal of Corporate Finance, 17, 33-44. https://doi.org/10.1016/j.jcorpfin.2010.07.004

Hovakimian, A., \& Li, G. (2012). Is the partial adjustment model a useful tool for capital structure research? Review of Finance, 16, 733-754. https://doi.org/10.1093/rof/rfq020

Hovakimian, A., Opler, T., \& Titman, S. (2001). The debt-equity choice. Journal of Financial and Quantitative Analysis, 36, 1-24. https://doi.org/10.2307/2676195

Huang, R., \& Ritter, J. (2009). Testing theories of capital structure and estimating the speed of adjustment. Journal of Financial and Quantitative Analysis, 44, 237-271. https://doi.org/10.1017/S0022109009090152

Hussain, H., Shamsudin, F., \& Jabarullah, N. (2015). Nonlinear speed of adjustment to lead leverage levels: Empirical evidence from firm level data. Indian Journal of Science and Technology, 8(30), 1-6.

Jensen, M. (1986). Agency costs of free cash flow, corporate finance and takeovers. American Economic Review, 76, 323-329.

Jensen, M., \& Meckling, W. (1976). Theory of the firm: Managerial behaviour, agency costs and ownership structure. Journal of Financial Economics, 3, 305-360. https://doi.org/10.1016/0304-405X(76)90026-X

Kraus, A., \& Litzenberger, R. H. (1973). A State-Preference Model of Optimal Financial Leverage. Journal of Finance, 28, 911-922. https://doi.org/10.1111/j.1540-6261.1973.tb01415.x

Kumbhakar, S. C., Hesmati, A., \& Hjalmarsson, L. (2002). How fast do banks adjust? A dynamic model of 
labor-use with an application to Swedish banks. Journal of Productivity Analysis, 18, 79-102. https://doi.org/10.1023/A:1015756527109

La-Porta R., Lopez-De-Silanes, F., Shleifer, A., \& Vishny, R. W. (1998). Law and finance. Journal of Political Economy, 106, 113-155. https://doi.org/10.1086/250042

Levine, R. (1999). Law, finance, and economic growth. Journal of Financial Intermediation, 8, 8-35. https://doi.org/10.1006/jfin.1998.0255

Lööf, H. (2003). Dynamic optimal capital structure and technological change. Working Paper, Swedish Institute for Studies in Education and Research (SISTER), Stockholm. https://doi.org/10.2139/ssrn.421460

Modigliani, F., \& Miller, M. H. (1958). The Cost of Capital, Corporation Finance and the Theory of Investment. American Economic Review, 48, 261-297.

Modigliani, F., \& Miller, M. H. (1963). Corporate income taxes and the cost of capital: A correction. American Economic Review, 53, 433-443.

Myers, S. (1977). Determinants of corporate borrowing. Journal of Financial Economics, 5, 147-175. https://doi.org/10.1016/0304-405X(77)90015-0

Myers, S. (1984). The capital structure puzzle. Journal of Finance, 39, 575-592. https://doi.org/10.2307/2327916

Myers, S. (2001). Capital Structure. Journal of Economic Perspectives, 15, 81-102. https://doi.org/10.1257/jep.15.2.81

Myers, S., \& Majluf, N. (1984). Corporate financing and investment decisions when firms have information that investors do not have. Journal of Financial Economics, 13, 187-222. https://doi.org/10.1016/0304-405X(84)90023-0

Oxley, L., \& Les, McAleer, M. (1993). Econometric issues in macroeconomic models with generated regressors. Journal of Economic Surveys, 7, 1-40. https://doi.org/10.1111/j.1467-6419.1993.tb00158.x

Öztekin, Ö., \& Flannery, M. (2012). Institutional determinants of capital structure adjustment speeds. Journal of Financial Economics, 103, 88-112. https://doi.org/10.1016/j.jfineco.2011.08.014

Pagan, A. (1984). Econometric issues in the analysis of regressions with generated regressors. International Economic Review, 25, 221-245. https://doi.org/10.2307/2648877

Rajan, R., \& Zingales, L. (1995). What do we know about capital structure? Some evidence from international data. Journal of Finance, 50, 1421-1460. https://doi.org/10.1111/j.1540-6261.1995.tb05184.x

Remolona, E. (1990). Understanding international differences in leverage trends. Federal Reserve Bank of New York Quarterly Review, spring issue, 3142.

Ross, S., Westerfield, R., \& Jaffe, J. (1993). Corporate Finance (3rd ed.). New York: Irwin/ McGraw Hill.

Titman, S., \& Wessels, R. (1988). The determinants of capital structure choice. Journal of Finance, 42, 1-19. https://doi.org/10.1111/j.1540-6261.1988.tb02585.x

\section{Copyrights}

Copyright for this article is retained by the author(s), with first publication rights granted to the journal.

This is an open-access article distributed under the terms and conditions of the Creative Commons Attribution license (http://creativecommons.org/licenses/by/4.0/). 